\title{
Attachment Parenting and Auditory, Language and Cognitive Rehabilitation
}

\author{
Heesoon Yoo ${ }^{1}$, Jinsook Kim ${ }^{1,2}$ \\ 'Department of Speech Pathology and Audiology, Graduate School, Hallym University, Chuncheon, Korea \\ ${ }^{2}$ Division of Speech Pathology and Audiology, College of Natural Sciences, Research Institute of Audiology and Speech Pathology, Hallym University, \\ Chuncheon, Korea
}

\section{애착육아와 청각언어인지 재활}

\author{
유 희 순 ${ }^{1}$ 김 진 숙,2
}

한림대학교 일반대학원 언어병리청각학과', 한림대학교 자연과학대학 언어청각학부· 청각언어연구소 ${ }^{2}$

\begin{abstract}
This study was aimed to review the history and definition of attachment parenting and to identify the types and merits of it and attachment plays based on attachment parenting. The early rehabilitation is essential to infants and toddlers with a congenital hearing loss for auditory and language development. Attachment parenting refers to close ties between parent and child based on skinship and emotional exchange. There are four different types of attachment: secure, insecure-avoidant, insecure-resistant, and insecure-disorganized. Among them, secure attachment is the optimal type through which an infant could learn to trust mother and maintain emotional stability even when the mother was absent. In Korea, the use ondol and podaegi, which can create attachment naturally had been used traditionally. Further Dandongsibhoon, a traditional play, is in accordance with the definition of attachment parenting. Therefore, Korean method of child rearing is proper for attachment parenting. It was known that attachment parenting enhanced self-esteem, increased independence, promoted social skills, and facilitated brain and language development, so that it could be used as a method of rehabilitation related to the development of auditory, language, and cognitive abilities. Recently developed the Korean Aural Rehabilitation for Infants integrated many attachment parenting means and sought to raise the efficacy of early rehabilitation. Conclusively, we hope that early rehabilitation applying attachment parenting services in Korea could be expanded so that even infants and toddlers with congenital hearing loss would grow up without having to go through many hearing-impairment problems.
\end{abstract}

Key Words: Attachment parenting, Emotional exchange, Traditional parenting, Korean Aural Rehabilitation for Infants.

Received: December 8, 2017 / Revised: January 15, 2018 / Accepted: January 23, 2018

Correspondence: Jinsook Kim, Division of Speech Pathology and Audiology, College of Natural Sciences, Research Institute of Audiology and Speech Pathology, Hallym University, 1 Hallimdaehak-gil, Chuncheon 24252, Korea

Tel: +82-33-248-2213 / Fax: +82-33-256-3240 / E-mail: jskim@hallym.ac.kr

\section{INTRODUCTION}

애착은 엄마와 아기의 밀접한 스킨십과 정서적 교류이다. 부 모가 아기와 사랑으로 스킨십과 상호교류를 강화시켜 아기가 정 서적으로 안정된 환경을 얻을 수 있도록 하는 것이 애착육아이 다. 이를 통해 아기는 부모와 강한 유대감을 형성하여 유아기는 물론 청소년기와 성인기에도 긍정적인 영향을 주게 된다(Bowlby, 1951). 이러한 형태의 애착 형성은 부모의 역할과 육아법에서 비롯되는데, Sears 부부는 1980년대 이후 출간한 여러 육아 저 서를 통해 애착육아법을 정의하고 대중화하고자 하였다(Sears
\& Sears, 2011). 이후 국제애착육아협회(Attachment Parenting International, API) 등의 단체가 애착육아법을 실행할 수 있도록 지원하였으며(Nicholson \& Parker, 1994), 2012년에 시사주간지 『Times지에서도 애착육아 내용을 표지로 내세워 애착육아가 효 율적이고 장점이 많은 육아법임을 강조하였다(Pickert, 2012). 우리나라에서는 애착육아가 1984년에 처음 소개되었고 이후 여러 방면에서 애착육아의 중요성이 강조되었는데 2012년에는 EBS 다큐멘터리에서 전통적 육아법이 애착형성에 적절하다고 설명하여 애착육아법이 더욱 주목을 받게 되었다(Kim, 2012). 애착육아는 아동의 전반적인 발달과 더불어 뇌 발달을 향상 
시키고 그에 따른 인지 및 사회적 상호작용능력이 향상되어 의 사소통능력도 함께 좋아질 수 있으므로(Gottman, 1997; Lee \& Kim, 2000) 애착육아는 조기에 이루어져야 효율적이다. 더욱 이 두뇌 발달은 부모와의 상호작용으로 활성화되고 시냅스와 뇌신경의 발달이 증가된다고 알려져 있는데 애착육아법을 활용 한 상호작용과 긍정적인 반응 및 자극은 생애 초기에 빠르게 발달하는 뇌 발달과 더불어 청각신경계의 신경 가소성에 중요 한 역할을 할 수 있다(Levi-montalcini, 1949; Wiesel \& Hubel, 1965). 조기에 부모와의 상호작용을 강화하는 애착육아법은 청 각과 언어기능의 발달에 기초가 되는 청각언어인지 발달에도 매우 큰 영향을 줄 수 있다. 왜냐하면 아기의 청각 발달은 생후 6 개월까지 청각적 경험을 통해 완성되고 그 이후 7 12개월 사 이에는 강도가 작은 소리도 감지할 수 있으며 자음과 모국어 습득이 가속화하여 첫 단어를 말할 수 있게 되는데 이러한 발 달 과정에서 애착육아는 뇌 발달과 청각신경계의 가소성을 촉 진시키는 역할을 하기 때문이다.

우리나라의 전통육아법은 안정애착 형성을 돕는 방법이 많 은데, 예를 들어, 온돌문화와 포대기 사용으로 자연스럽게 밀착 된 스킨십을 하고 아기와 엄마가 함께 잠자면서 모유수유를 하 며, 도리도리, 잼잼과 같은 전통놀이인 '단동십훈(檀童十訓)'을 사용하는 점이다(Choi, 2013; Chung, 2003)(Appendix 1). Lim $\& \operatorname{Kim}$ (2010)은 전통놀이를 통한 육아법이 아기의 정서를 안 정되게 하여 자존감과 독립심을 향상시키고 사회성 발달을 촉 진한다고 하였고, 초기의 긍정적인 반응으로 아기의 뇌 발달을 촉진시킬 뿐 아니라 언어 발달에도 도움을 주는 것으로 알려져 있다(Lee \& Kim, 2000; Sears \& Sears, 2011).

따라서 본고는 선행 문헌을 조사하여 애착육아의 역사와 정 의를 고찰하고, 애착육아의 유형 및 장점과 관련된 애착놀이를 확인하여 청각언어인지 재활에 적용 가능성을 알아보고자 하 였다. 더불어 우리나라의 전통육아와 애착육아의 밀접한 관련 성을 바탕으로 청각장애 영유아를 위한 청각언어인지 재활법에 자연스럽게 애착을 형성할 수 있는 자연스런 전통육아법의 접목 가능성을 분석하였다. 결론적으로 이러한 애착육아법이 현재 개 발되고 있는 영유아의 조기 청능 재활(Korean Aural Rehabilitation for Infants, KARI) 프로그램에 어떻게 적용될 수 있는 지 확인하고 청각장애 영유아는 물론 정상 영유아에게도 애착 육아법이 실질적으로 효율적이고 실현가능한 육아법인지 고찰 하고자 하였다.

\section{애착육아의 역사와 정의}

애착육아는 부모와 자녀 간의 강력하고 밀착된 결속력을 바 탕으로 한 육아법이다. 1930년대부터 정신분석가들은 영유아 와 주 양육자 간의 관계가 아동의 성격 발달에 끼치는 영향에
대해 연구하였으며 그 과정에서 애착육아에 대한 관심은 1951 년 John Bowlby의 저서 "Maternal Care and Mental Health」와 비슷한 시기에 개봉된 두 편의 영화 "Grief: A Peril in Infancy, 『A Two-Year-Old Goes to Hospital」에서 나타나기 시작하였다. 주요 내용은 부모로부터 돌봄을 받지 못하여 나타나는 정신건 강상의 위험에 대한 내용을 쟁점화하여 그 당시 사회적인 큰 반 향을 일으켰다. 저자는 아기와 엄마의 지속적인 애착관계를 통 해 아기의 정신건강이 튼튼하게 된다고 주장하였다. 애착육아 의 개념은 그 이후에 아기의 신호에 대한 엄마의 신속하고 긍정 적인 반응과 밀접한 스킨십 등이 좋은 애착을 형성할 수 있다 는 연구결과로 소개되었다(Ainsworth et al., 1978).

1980년대 Sears 부부는 생후 3년 정도까지 부모가 아기와 많 은 시간을 보내며 스킨십 자주 하기, 엄마와 아기가 함께 자기, 모유수유 하기, 아기의 요구에 민감하게 반응하기, 천 또는 포대 기를 이용하여 업거나 안고 다니기 등에 대한 저서들을 출간하 여 애착 형성을 위한 특정적 육아법을 대중들에게 알리고자 하 였다. 대표적인 저서로는 ${ }^{\circledR}$ Creative Parenting: How to Use the Attachment Parenting Concept to Raise Children Successfully from Birth Through Adolescence』, "The baby book』 등으로 이후 연구를 통합하여 아기의 안정애착 형성을 위한 엄마의 역 할과 육아법을 강조하며 이를 '애착육아(attachment parenting)'라고 정의하였다(Sears, 1983). 1990년대에는 스킨십을 무 시한 서양식 육아방식의 문제점이 강조되면서 애착육아를 지 지하는 여러 단체의 움직임으로 이어졌다. 그 예로 산모도우미 를 양성하는 교육기관인 Doulas Of North America (DONA) 는 출산 전과 후에 산모와 아기의 유대감이 생성되도록 병원에 서 출산 전 특정 분만 교육을 하며 애착육아의 중요성을 알렸 다. DONA는 병원 내에서 전문가가 교육하는 시스템을 도입하 여 임신 후 분만 교육, 신생아 관리, 모유수유 등의 내용이 포함 된 라마즈 교육을 받고 출산 직후 엄마와 신생아가 스킨십을 자연스럽게 할 수 있도록 하였다(Kennedy et al., 1992). 더 나 아가 전 세계적으로 네트워크를 형성하고 있는 국제애착육아협 회(API)는 온라인을 통해 애착과 관련된 정보를 제공하고 부 모교육에 앞장서며 애착육아를 실행하여 행복한 가족생활이 되도록 하고, 아이들이 성장하면서 지역사회에서 잘 적응할 수 있도록 지원하는 역할을 하여 왔다(Nicholson \& Parker, 1994). 또한 API는 Journal of Attachment Parenting을 통해 'Perceived partner support in pregnancy predicts lower maternal and infant distress (Stapleton et al., 2012)' 등의 임신 관련 연구 부터 모유수유, 스킨십, 수면 등에 대한 내용은 물론 'Parenting and late adolescent emotional adjustment: Mediating effects of discipline and gender (McKinney et al., 2011)' 등의 청소년기 문제와 가족의 삶에 대한 내용까지 애착육아 원칙을 
지지하는 내용을 분야별로 모아서 출간하고 배포하여 애착육 아와 관련된 연구를 독려하고 있다. 2012년에는 미국 시사주간 지 『ime」이 표지 기사로 모유수유와 애착육아를 중점적으로 다루며 애착육아가 매우 효율적이고 장점이 많은 육아법임을 강 조하였다. 특히 'Are you mom enough?'라는 제목과 모유수유가 강조된 표지로 미국의 엄마들이 엄마로서 효율적인 교육을 하 는 역할을 하고 있는지에 대한 질문을 던지며 모유수유와 정서 적 유대관계를 통한 부모와 아기의 애착 형성을 강조하였다 (Pickert, 2012).

우리나라에서는 1984년 장휘숙의 영아의 애착 발달이란 논 문으로 애착육아가 소개되기 시작하였다. 이후 국내 연구에서 개인의 행복과 독립을 중요시하며 원거리로 상호작용을 이용 한 서구의 육아법에 비해 우리나라는 부모와 자녀 간의 관계를 중요시하여 스킨십을 자주 하고 대인 지향적이며 관계 지향적 인 육아법을 중심으로 근거리 상호작용을 통해 아기가 엄마의 감정을 더 잘 이해할 수 있는 환경에서 육아를 하고 있다고 주 장하였다(Jin \& Yoo, 2005). 이렇게 자란 우리나라의 아기들은 타인의 감정을 인지하고 배려하는 긍정적인 대인관계능력을 가 질 수 있게 된다고 정리하고 있다(You, 2003). 더 나아가 엄마 의 역할은 12 18개월 영유아에게 매우 중요하다는 점을 강조 하며 우리나라의 자연스런 애착육아법으로 자란 아기들은 아 동기뿐 아니라 청소년기에 형제자매나 친구 관계에도 긍정적인 영향을 줄 수 있다고 보고하여 전통적 육아법의 장점을 강조하 고 있다(Kim et al., 2005).

2012년 EBS 다큐멘터리에서 우리나라의 전통적 육아법이 특히 애착 형성에 적절한 육아법임을 주장하였다(Kim, 2012). 전통적 육아법의 예는 온돌에서 아기와 함께 잠자기, 가족의 공동 아기 돌봄 체제, 포대기를 이용한 엄마와의 밀착으로 인 해 형성되는 애착관계 등이다. 특히 포대기를 사용하는 방법이 애착육아에 적절하다고 하여 뉴욕 중심가의 육아용품점에서 우리나라의 포대기로 아기를 업는 방법을 교육하는 과정을 다 큐멘터리의 시작 부분에 제시하고 있다. 부드러운 천을 이용하 여 아기를 앞이나 옆으로 메고 다니는 방법의 대표적인 예가 우 리나라의 포대기지만, 여러 나라의 부모들도 본능적으로 이러 한 방법이 안전하고 건강하다고 믿고 있다. 예를 들어 2007년 영국의 $\mathrm{BBC}$ 가 제작한 ${ }^{\mathrm{Bringing}} \mathrm{Up} \mathrm{Baby \_}$ 에서 소개한 아마존 부족의 육아법은 천을 이용하여 항상 아기를 안고 다니는데 아 기의 발달에 긍정적인 영향을 미치고 아기가 성장한 후에도 항 상 자신감에 차 있고 우울감이 없다고 보고하였다(Goodwin, 2007). 우간다의 엄마들도 출생 직후부터 얇은 천을 이용해 아 기를 지속적으로 안고 다닌다고 보고하고 있는데 이렇게 자란 아기들은 시각적으로 사람의 얼굴을 보며 미소를 짓거나 거울 을 보며 자신의 얼굴을 응시하기가 가능하고 앞 팔로 버티며
앉을 수 있는 등의 초기 신체 발달이 빠르다고 한다(Bhavnagri, 1984). 또한 유튜브에 세계 각국의 부모들이 우리나라의 포대기 사용법에 대해 자기만의 독특한 방법을 보여주는 영상이 다수 소개되어 있어 포대기가 세계적으로 선풍적인 인기를 끌며 많 은 관심을 받고 있다는 점을 시사하고 있다(Tettinntil, 2008).

전통적으로 우리나라는 엄마를 포함한 모든 가족들이 육아 에 참여하고 전통놀이를 통해 아기와 성인 간의 강한 유대감을 형성하여 아기가 성인의 정서표현을 쉽게 습득하고 다른 사람 을 즐겁게 하는 대인관계의 기술도 익히게 된다. 이러한 육아법 은 자신과 다른 사람의 감정과 정서를 이해하고 조절하여 일상 생활에 사용할 수 있는 적응능력을 의미하는 정서지능 (emotional intelligence)도 잘 발달시킬 수 있다.

\section{애착육아와 청각언어인지 재활}

아기의 내이는 태아기 20 주에 발달이 완성되어 생후 6 개월까 지 청각적 경험을 통해 중추 청각신경계의 발달을 세분화한다. 태내에서는 양수를 통해 소리가 전달되므로 저주파 소리를 더 잘 듣고 $1,000 \mathrm{~Hz}$ 이상의 주파수에서는 $20 \sim 30 \mathrm{~dB}$ 정도의 강 도가 감쇄되어 전달된다. 따라서 발달이 완성된 와우 기능으로 주파수 분석능력은 태내기부터 발달한다. 그러므로 분절적 정 보보다 리듬과 억양과 같은 초 분절적인 정보를 더 먼저 이해 할 수 있어 운율이 있는 동요나 자장가 등을 듣고 습득하며 태 아나 신생아는 초기 청각인지 발달을 하는 것으로 알려져 있다. 아기는 생후 6 개월까지는 다양한 말소리를 들으면서 점차 주파 수 분석능력이 세분화되고 분절적인 정보도 이해하고 저장할 수 있게 된다. 7 개월부터 12 개월 사이에는 강도가 작은 소리도 감지를 할 수 있을 뿐 아니라 모국어와 외국어도 분별하여 저 장하며 모국어 습득능력이 향상된다. 청각인지 학습을 위해 아 기는 인지기억, 연관 학습, 통계적 학습, 사회적 상호작용 등의 학습 메커니즘을 사용하여 이를 통해 습득한 언어를 정보화하 고 말을 할 수 있게 된다(Kim, 2017).

청각신경계의 가소성은 연령에 따라 다르게 발달하는데 어 린 나이에 많은 양이 신속히 발달된다. 영유아기에는 말초신경 계의 자극이 중추신경계의 발달을 주도하고 활성화시키는데 두 신경계는 친밀하게 연계되어 조기 발달과 신경 가소성에 영 향을 미치는 것으로 알려져 있다(Harrison et al., 2005). 이러 한 결론은 수십 년간의 동물 연구를 통해 증명되었다. 예를 들 어, 말초와 중추신경계의 연계성은 병아리나 고양이의 말초시 각신경계의 태생 전 박탈이나 손실로 인해 중추신경계의 해부 생리 형태가 변화하는 것을 확인하며 입증되었다(Levi-montalcini, 1949; Wiesel \& Hubel, 1965). 특히 아주 어린 동물을 대상으로 한 청각신경계의 실험에서 한쪽 와우를 제거했을 때, 청력의 손실뿐 아니라 뇌간이나 중뇌의 청각신경 분포와 신경 
망 경로가 변화되는 것이 확인되어(Hashisaki \& Rubel, 1989) 초기 말초자극이 중추 발달에 얼마나 큰 영향을 주는지 입증하 였다. 더욱이 이러한 현상은 연령에 따라 차이가 있었는데, 고 양이의 경우 60 일 이후에 제거했을 때와 쥐의 경우 24 일 이후에 제거했을 때에 중추신경계의 경로와 발달에 영향을 주지 않으 므로 초기의 자극이 중추신경계에 미치는 영향이 크다는 것을 확인하였다(Clopton \& Silverman, 1977). 또한 주파수에 따라 반응 영역이 다르게 작용하는 주파수 특이성(tonotopicity)과 관련된 청각신경계의 가소성은 태생 후 1 2주 안에 나타나고 성장 후에는 발달하지 않는 것으로 친칠라의 중뇌 연구에서 밝 혀져 인간의 경우도 초기 자극이 말초와 중추의 연계적 발달 에 치명적일 수 있다는 점이 확인되었다. 특히 인공와우 수술 시기에 따른 언어인지 수행능력을 연구한 결과에서 연령에 따 라 신경 가소성에 대한 발달이 달라지는 것을 확인하였는데 나 이가 점점 많아질수록 신경 가소화가 감소되어 중추신경계의 발달이 느려지기 때문에 태어나서 청각장애가 있을 경우 조기 에 말초와 중추 청각신경계의 구조화된 상호 발달의 연계성을 높이도록 청각 보조기기를 일찍 활용하여 활발하고 긍정적인 상호작용을 통해 신경 가소성을 높이도록 하여야 한다고 연구 자들은 주장하고 있다(Harrison et al., 2005). 이는 2.5세 이전 에 인공와우 수술을 한 경우 이후에 인공와우 수술을 한 영아 들과 비교할 때 표현언어, 화용 등의 언어 발달에서 정상에 가 까운 수행능력을 보여 조기 재활에 대한 중요성을 입증하였고 (Tobey et al., 2013), Sharma et al.(2007)도 청각피질유발전위 (cortical auditory evoked potential)의 잠복기 연구를 통해 중 추의 인지 발달을 대표하는 P1의 잠복기가 정상범위에 속할 수 있기 위해서 3.5 세 이전 시기에 인공와우 수술을 받아야 한다 고 보고하여 조기에 보장구를 이용한 청각 자극과 청각언어인 지 재활에 대한 중요성을 강조하였다.

아기와 부모의 정서적 상호작용은 두뇌 발달을 돕고, 애착육 아는 전두엽 피질이 담당하는 사회정서적 행동 조절에 긍정적 영향을 주어 영유아기에는 성인과의 긍정적 상호작용에 의해 시냅스와 뇌신경 세포 발달이 증가된다(Schore, 1996). 이와 관 련된 영유아기의 교육과 두뇌 발달의 연구에서, 연구자는 뇌는 출생 시 완전히 형성되어 있는 것이 아니라 출생 후에 유전 요 인과 환경과의 상호작용에 의해서 약 $75 \%$ 가 발달되며, 특히 영 유아기에 가장 왕성하게 시냅스가 발달하므로 이 시기의 상호 작용이 강조된 육아방법은 시냅스의 발달을 활성화하여 뇌세 포 연결망을 구조화하는 데 매우 중요하다고 보고하고 있다. 더 나아가 아기의 비언어적 의사소통이나 일상적인 상호작용도 뇌 발달에 연계되어 있으므로 아기와 눈 맞춤을 하고 아기의 발성 에 반복적으로 응답하는 방법으로 아기의 뇌 발달을 도울 수 있 다는 연구결과도 제시되었다(Lee \& Kim, 2000; Sears \& Sears,
2011). 즉, 지속적인 관심으로 아기의 미세한 신호에도 잘 반응 하고 아기의 옹알이에 미소 지으며 긍정적인 말로 응답할 경우 아기의 청각언어 영역의 뇌 발달을 활성화하여 아기는 더 많은 발성을 하게 되고 부모와 아기가 상호적으로 반응하는 방식이 다양해져서 전반적인 뇌 발달뿐 아니라 청각언어인지 발달에 치명적 영향을 미치는 것으로 이해할 수 있다.

일반적으로 선천적 장애아의 태생 후에 겪는 가족들의 스트 레스는 정상아 태생 후보다 높다. 이는 전반적인 육아 외에 의 료 및 재활과 같은 특수한 서비스를 제공해야 하는 어려움 때 문인 것으로 알려져 있다. 그러나 애착유형별 양육 태도 및 양 육 스트레스 척도에 의한 연구에서 애착육아법으로 아기를 키 운 경우 세상 사람들의 지지로 부모의 양육태도가 긍정적이 되 며, 장애의 유형과 상관없이 부모의 육아 스트레스는 낮은 결과 를 보이는 것으로 밝혀져(Yu et al., 2004) 애착육아는 장애 아 동에 더 효율적인 육아법으로 나타났다. 특히 청각장애는 약 $50 \%$ 의 경우가 유전적인 요인으로 발생하고 그중 약 $70 \%$ 가 난 청 외에 다른 신체적 이상이 없는 비증후군에 속하며 그중 약 $77 \%$ 가 열성유전으로 나타나서, 부모가 모두 건청인데 선천적 으로 비증후군적 열성유전으로 아기가 난청인 경우를 흔히 볼 수 있다(Kim, 2017). 그러한 경우 건청 부모는 더욱 스트레스 를 받게 되지만, 애착육아의 장점과 개념을 이해하면 조기 청 각언어인지 발달에 긍정적인 영향을 미칠 것으로 생각된다.

\section{애착의 유형과 육아방법}

Ainsworth et al.(1978)은 아기와 엄마의 분리와 재결합 상황 에서 아기의 반응을 분석하여 애착의 유형을 다음 네 가지, 안 정(secure)애착, 불안정-회피(insecure-avoidant)애착, 불안정저항-(insecure-resistant)애착, 불안정-무질서(insecure-disorganized)애착으로 분류하였다. 첫 번째, 안정애착은 아기가 엄 마를 믿고 있으므로 엄마가 눈에 보이지 않는 먼 곳에서도 정 서적으로 안정된 상태로 아기가 지낼 수 있는 애착 형성을 의미 한다. 더욱이 안정애착은 장난감을 가지고 노는 놀이 상황에서 엄마와 상호작용하려는 욕구가 높아 아기가 먼저 엄마와 상호 작용을 시도하고, 엄마가 안아 주는 행동에 긍정적인 표현을 하 며, 자신이 원하는 것을 찾기 위해 적극적인 행동을 한다. 또한 아기는 엄마와 분리될 때 힘들어하지만 재결합을 하게 되면 바 로 안정을 되찾을 수 있다. 두 번째, 불안정-회피애착은 엄마에 대한 애착에 대해 혼란을 보이는 경우이다. 즉, 아기와 엄마가 서로 동시에 애착욕구를 보이는 상황에서 안정애착처럼 보이 나, 아기와 엄마의 애착욕구가 다른 상황에서는 아기는 엄마의 스킨십이나 상호작용 시도에 반응하지 않고 혼자서 장난감을 가지고 노는 행동을 하며 엄마와 상호작용을 먼저 시도하지 않 는다. 아기는 엄마와의 분리와 재결합 상황에 대한 변화를 무 
시하는 경향이 있으며 혼자서는 놀이에 집중을 못하고 불안해 하며 엄마를 계속 주시하는 모습을 보이는 행동을 한다. 세 번 째, 불안정-저항애착은 엄마가 비일관적인 태도로 애착을 형성 한 유형으로, 분리하는 상황에서도 매우 힘들어하며 재결합을 하여도 엄마에게 다가가지 않고, 엄마와 함께 놀이를 제대로 하 지 않으며 화난 상태로 장난감을 두드리는 등의 이상행동을 한 다. 네 번째, 불안정-무질서애착은 주로 고위험군 아동에게 많 이 나타나는 유형인데, 아기가 엄마와 분리된 후 재결합했을 때 에도 아기는 엄마에게 두려움을 가지고 다가가지 않으며 일반 적으로는 설명할 수 없는 일관성 없고 모순된 행동을 한다. 이 러한 반응은 놀이 상황에서도 지속적으로 나타날 수 있다.

안정애착 형성을 위해 가장 대표적인 육아방법은 스킨십이다. 업어 주고 안아 주는 부모 품에서 자란 아기는 상호작용의 빈도 가 높아져서 안정애착의 행동을 보일 수 있다(Sears \& Sears, 2011). 이러한 스킨십을 구체적이고 적극적으로 할 수 있는 방 법 중 하나가 ‘아기 마사지’이다. 생후 100 일 전후의 아기는 엄마 의 스킨십이 강조된 마사지를 통해 정서적 안정과 만족감을 느 끼고 덜 울게 되며 신체 발달이 골고루 이루어질 수 있다. 또한 부모가 어린 아기를 가슴에 안고 맨살로 스킨십을 하면 부모의 심장 소리를 듣고 청각적인 자극을 받으며 부모의 호흡에 따라 가볍게 아기의 머리가 흔들리면서 전정기관이 자극받게 되어 진정효과를 갖게 된다고 연구자들은 보고하고 있다(Becker et al., 1991).

모유수유도 안정애착을 형성할 수 있는 방법이다. 모유수유 는 아기에게 좋은 영양을 공급하며 엄마와 아기의 친밀감을 높 일 수 있고 엄마와 아기만의 공간 속에서 서로의 사랑을 확인 할 수 있는 소중한 시간을 갖게 해 주기도 한다. 또한 아기가 울 음으로 신호를 보내면 엄마가 신속한 반응으로 아기에게 믿음 과 안정을 줄 수 있는 방법이다(Granju \& Kennedy, 1999). 더 욱이 이를 빈번하고 자연스럽게 수행할 수 있는 장점도 있다. 더욱이 모유에는 질병을 막아 주는 항체가 포함되어 있어 여러 가지 질병으로부터 아기를 보호해 주는 역할을 하므로 생후 1 년까지는 모유수유 하는 것이 아기의 건강에 매우 좋다는 연구 결과도 있다(Glick, 1999).

아기와 함께 자는 것도 좋은 안정애착을 형성하는 방법이다. 거의 전 세계의 부모들이 아기와 함께 잠을 잔다. 그러나 서구 화되고 현대적인 부모는 아기와 함께 자는 것을 마치 어리석은 예전 방법을 따르는 것처럼 생각하기도 한다. 잘 준비된 가족 잠자리에서 아기와 함께 자면 평안한 밤을 지내고 가족이 더 가까워질 수 있으며 다른 방에서 아기를 혼자 재우는 것보다 안전하다. 수면시간 동안 아기와 함께 호흡하고 체온을 직접적 으로 느끼기 때문에 아기의 신체적 변화를 즉각적으로 알 수 있어 아기의 상태에 따라 신속한 대처가 가능하므로 애착관계
형성에 매우 좋다(Granju \& Kennedy, 1999). 미국 보건원(National Institutes of Health, 1994)에서는 영유아 돌연사(sudden infant death syndrome) 예방을 위해 1994년부터 'safe infant sleep' 캠페인을 통해 ‘아기와 함께 자기’ 등을 적극적으로 권장 하고 있다. 또한 수면 시 아기와 거리가 가깝기 때문에 모유수 유를 하기에도 용이하다. 그 외 애착육아의 방법으로 상호작용 을 강조한 놀이법도 있다.

\section{우리나라의 전통육아와 애착육아}

우리나라의 전통적 난방 방식인 온돌은 고려시대부터 사용 되어 왔다. 우리나라의 온돌은 주거공간으로 가족들이 저녁에 모여 앉아 하루 일과를 나누고 할머니의 옛이야기를 들으며 추 운 겨울을 따뜻하게 보낼 수 있는 가족의 의사소통 장소이고, 온 가족이 한 방에서 아기와 함께 잠을 잘 수 있는 자연스러운 환경을 조성하였다. 우리는 자연스럽게 이러한 공간에서 아기와 함께 생활하며 자장가를 불러주고 품 안에 안거나 업어서 재우 는 생활을 한 민족이다(Chung, 2003). 엄마와 아기가 함께 자면 서 부드러운 스킨십을 하면 친밀도를 높이고 아기의 뇌 발달에 도움이 되며 정서적 안정뿐 아니라 성장호르몬 분비를 왕성하 게 하여 신체 발달도 돕는다고 보고한 뇌 과학자들의 자료를 볼 때(Granju \& Kennedy, 1999), 이러한 전통적인 우리나라의 육아환경의 우수성이 입증되었다고 할 수 있다.

우리나라에서 포대기는 이미 오래전부터 사용되어진 것으로 확인되었다. 할아버지가 손자를 위해 쓴 육아서인 『양아록』에 의하면 명종 6년인 1551년에도 아기를 돌볼 때 포대기를 사용 했다는 기록이 있고, 18 19세기 조선시대 화가인 신윤복의 그 림인 '아기를 업은 여인'과 '장옷을 입은 여인'에도 포대기로 아 기를 업은 그림이 있어 오래전부터 포대기를 사용하고 있었다 는 것을 증명하고 있다(Huh, 2010). 포대기로 육아를 했던 우리 나라 전통육아는 현재도 사용되고 있다. 아기가 걸을 수 있는 12 개월까지는 포대기를 이용하여 아기를 엄마의 몸에 밀착하여 키우는 모습은 우리나라에서 흔히 볼 수 있는 육아법이다. 이러 한 방법은 포대기가 자궁과 유사한 환경을 조성하여 아기가 최 적의 안정감을 느끼고 엄마와 함께 많은 것을 공유할 수 있게 하며 친밀감이 높아질 수 있다. 더욱이 포대기를 이용해 항상 업고 다니면 아기를 질병으로부터 보호할 수 있다고 연구자들 은 보고하고 있다(Chung, 2003). 더 나아가 엄마가 아기를 안전 하게 돌보면서 다른 일상적인 일도 할 수 있고, 엄마와 아기가 서로 공유하는 일상이 많아지고 서로 더 이해하며 친숙해지는 환경을 조성한다고 보고되었다. 선행연구에 의하면 많이 업어 준 아기들은 더 만족감을 느끼고 우는 횟수가 감소하여 엄마와 아 기 사이에 매우 건강한 애착관계가 형성된다고 보고되었다(Anisfeld et al., 1990). 
우리나라의 독특한 온돌과 포대기 문화는 아기와 함께 자면 서 시간과 장소에 관계없이 아기가 필요할 때 수유를 할 수 있 는 상황이 자연스럽게 조성되었다. 온돌에서 아기와 함께 자면 서 밤에도 모유수유가 용이했으며, 포대기를 이용해 아기를 업 고 있으면 낮에 일을 하다가도 손쉽게 모유수유가 가능했기 때 문에 우리나라는 정해진 시간에 수유하는 것이 아니라 아기의 상태를 고려하여 수시로 모유수유를 하여 아기의 신호에 민감 하게 반응할 수 있었다. 이러한 과정에서 아기와 엄마 사이에 신뢰감이 쌓이며 자연스럽게 안정애착을 형성할 수 있었다. 이 런 모유수유 방법은 전통적으로 훌륭한 애착 형성을 가능하게 한 방법이라 할 수 있다.

우리나라의 전통놀이인 단동십훈(檀童十訓)은 단군시대부 터 구전되어 온 신체 발달 및 성장을 돕는 놀이이다. 아기와 엄 마의 상호작용을 강조하고 교훈이 담겨 있는 신체를 이용한 놀 이인 단동십훈은 모두 의미가 있는 불아불아(弗亞弗亞), 시상 시상(詩想詩想), 도리도리(道理道理), 지암지암(持闇持闇), 곤 지곤지(坤地坤地), 섬마섬마(西摩西摩), 업비업비(業非業非), 아 함아함(亞合亞合), 짝짝궁짝짝궁(作作弓作作弓), 질라아비 휠 휠의(羅呵備 活活議)로 구성되어 있다(Appendix 1). 청각적으 로 주의집중을 유도하여 지각능력과 기억을 증진시키고 모방 능력을 향상시킬 뿐 아니라 청각언어인지 발달 초기 자극 요소 인 주요 모음을 포함하고 있다. 더욱이 이를 동작과 함께 재미 있는 놀이로 엄마나 어른과 함께 하도록 되어 있어 놀이말에 아 기의 집중도가 향상되도록 하고, 반복적 운율로 노래처럼 불러 서 언어자극에 매우 적절한 자료로 사용될 수 있다. 또한 어른 이나 엄마와 아기가 마주 보고 놀이를 하기 때문에 눈 맞춤과 스킨십을 하게 되어 놀이하는 동안 아기와 자연스럽게 안정애 착 형성이 가능한 구조적 놀이이다. 더욱이 특별한 도구나 장난 감이 필요하지 않고 장소와 시간에 구애받지 않으면서 상호작 용이 가능한 이 전통놀이는 아기와 엄마의 애착 형성은 물론 여러 영역별 놀이의 형태를 갖추고 있어 요즘 다시 주목을 받고 있다. 최근 카카오톡 모바일콘텐츠 서비스인 '카카오페이지'에 '왕실 영재육아 단동십훈'이란 육아놀이가 출시되고 두뇌와 정 서지능 발달에 효율적이라 소개되어 부모들의 관심을 받고 있 다(Choi, 2013). 다양한 도서와 영상이 SNS에 소개되어 있어 실 질적으로 육아에 많이 적용되고 있다.

\section{애착육아의 장점}

애착육아는 아기의 자존감을 향상시키고, 독립심을 높이고, 사회성 발달을 촉진하고 뇌 발달과 언어 발달에 도움을 준다. 안정애착이 잘 형성된 아기는 몸과 마음이 편안한 상태를 느끼 게 되고 자존감과 독립심이 높은 자기주도형이며 타인에 대한 배려심이 많은 사람으로 성장할 수 있다. 또한 타인의 감정을
읽을 수 있게 되어 사회에서 대처능력이 좋아져서 자연스럽게 사회성이 잘 발달하게 된다. 더 나아가 긍정적인 상호작용으로 영유아기에 신경계의 활발한 반응을 유도하여 뇌 발달과 언어 발달에도 좋은 영향을 끼친다.

엄마의 일관된 관심은 아기가 자신을 긍정적으로 받아들일 수 있게 하여 자신을 소중히 여기고 자존감이 높은 사람으로 성 장하게 한다. Sears \& Sears(2011)에 의하면 아기가 어려움을 겪 을 때 엄마가 도움을 주면 아기는 평온한 상태를 유지하며 아기 의 첫 사회관계자인 부모와의 관계에서 굳건한 신뢰를 바탕으로 이루어질 수 있다고 하였다. 이러한 신뢰는 자아 형성 과정에서 자존감을 향상시킬 수 있고 자신과 타인을 소중히 여기게 된다.

독립심은 아기가 스스로 도전하는 과정에서 형성된다. 아기 는 태어나면서부터 매우 의존적인데 이러한 의존욕구가 충족 되면 문제해결을 자기주도적으로 해결할 수 있고 정서적으로 안정되며 높은 자신감과 의지로 어려움을 해결하고 새로운 분 야에 도전하는 데 머뭇거리지 않게 된다. 예를 들어 5 6세가 될 때까지 부모에게 의존적인 아기는 출생 후 2년 동안 초기의 의존욕구가 제대로 충족되지 않았기 때문일 가능성이 높은 것 으로 생각되고 있다. 더욱이 초기의 의존욕구가 충분히 채워지 지 않은 아기는 성인이 되어서도 부족했던 의존욕구를 채우려 하는 ‘의존성 성격장애'가 나타날 수 있다고 보고하고 있다. 이 와 반대로 초기의 의존욕구가 충분히 채워지면 3세쯤에 부모 와 떨어져도 안정적으로 생활할 수 있다. 자존감과 독립심이 강 하면 자기 판단능력과 분별력이 있는 자기주도적 성장과 발달 로 자기 결정능력 향상뿐 아니라 학업성취능력도 우수하다고 보고하고 있다(Hong \& Lee, 2017).

잘 형성된 애착관계에서 사랑으로 자란 아기는 자주 울거나 보채지 않게 되는데 이는 캐나다 맥길대 의과대학 부속 몬트리 올 병원에서 1985년 실시한 실험연구에서 증명되었다. 연구자 들은 아기를 많이 안아 준 그룹과 그렇지 않은 그룹으로 나누어 비교 실험을 하여, 생후 6주를 기점으로 많이 안아 준 아기들의 울음이 평균적으로는 $43 \%$, 저녁시간에는 $51 \%$ 감소했다는 결 과를 보고하였다(Hunziker \& Barr, 1986). 또한 긍정적인 반 응을 자주 받은 아기는 초기 우뇌 발달이 촉진되어 스트레스 를 받는 상황에 놓이게 되었을 때 대처를 잘하게 되어 문제 상 황을 잘 극복할 수 있으며 이후의 감정적 대처에도 많은 영향 을 준다고 보고하고 있다. 따라서 정서적 안정뿐 아니라 상대방 마음을 잘 읽게 되고 더 나은 학습능력과 사회적 기술을 배울 수 있고 또래 집단으로 애착이 옮겨 가는 청소년기와 학교생활 에서도 양호한 사회성을 나타내었다.

\section{애착놀이}

Solter(2015)는 안정애착 형성을 위해 애착놀이의 필요성을 
강조하였다. 애착놀이는 부모와 아기의 상호작용 놀이이다. 아 기가 ‘나랑 놀아 주세요' 하고 요구할 때 부모가 민감하게 반응 하며 일상생활에서 하는 놀이로 특별한 장난감을 사용하지 않 고 장소와 시간에 구애받지 않고 놀이를 하는 것을 의미한다. 아기가 주도적으로 놀이를 시작하고 부모가 따라 주면 아기는 자신감이 높아지고 스스로 사랑받는 느낌을 받게 된다. 부모가 아기에게 이미 친숙해진 놀이를 이용하거나 우발적인 상황을 이용한 우스꽝스러운 놀이로 재미있게 하고 웃는 모습을 만들 어 주는 놀이가 애착놀이이다. 아기는 모방을 통해 학습을 하 기 때문에 엄마가 웃으면 함께 웃고 우울한 얼굴 표정을 모방 하며 감정을 전달받는다.

아기는 자주 반복된 상황 속에서 다음 상황을 예측할 수 있 으므로 모방과 반복으로 학습이 가능하며 청각언어인지 발달 을 촉진하는 도구가 될 수도 있다. 연구자들은 기능성 자기공명 영상장치(functional magnetic resonance imaging)를 이용한 뇌 실험 결과로 뇌의 거울신경체계가 사람의 말소리나 입 모양 을 거울처럼 따라하며 청각언어인지 발달을 촉진한다고 주장 하였다(Dinstein et al., 2008). 엄마는 아기가 모방을 할 수 있 는 가장 좋은 본보기가 될 수 있어 아기의 청각, 언어, 신체 및 사회성 발달 등에 지대한 영향을 미칠 수 있다. 아기와 항상 함 께 생활하며 본보기를 보이는 것이 가장 좋은 방법이지만 맞벌 이와 핵가족화가 대세인 요즈음은 출근 전이나 퇴근 후 질적으 로 우수한 효율적인 놀이방법도 추천되고 있다. 출근 전이나 퇴 근 후에 보이는 부모의 세심한 배려와 진정한 사랑은 아기에게 안정감을 주어 부모와 안정애착 형성이 가능하다고 육아의 양 보다 질을 강조하는 연구자는 주장하고 있다. 아기와 놀이를 할 때 훈련을 목적으로 하거나 아기를 통제하지 말고 엄격하고 극 단적인 방법은 피하며 아기에게 따뜻하고 즐거운 반응이 올 수 있도록 놀이를 하면 애착이 더욱 잘 형성된다(Sears \& Sears. 2011).

애착놀이의 예로 이미 소개한 전통놀이인 단동십훈 외에 상 황에 따른 전통놀이로 $\operatorname{Lim} \& \mathrm{Kim}(2010)$ 은 업어 줄 때는 '어부 바', 배가 아플 때 '할미 손은 약손' 자세를 바르게 할 때 '서울 보여주기', 다쳤을 때 ‘울 아기 장사', 배변 훈련 시 '단지 팔기' 등 을 통해 일상생활 속에서 재미있게 할 수 있는 전통놀이로 소 개하고 있다. 우리나라의 전통놀이는 율동과 리듬이 있고 반복 적으로 쉽게 따라 할 수 있도록 구성되어 있어 좋은 애착놀이 로 활용할 수 있다. 또한 쓰다듬기, 안아 주기, 배 푸하기 등의 스킨십을 강화한 놀이도 애착 형성에 도움이 된다(Kwak et al., 2005). 그 외 아기의 옹알이를 듣고 마치 대화하듯이 "어, 그랬 어?"라고 반응하거나 아기가 “아 ”라고 말하면 아기의 옹알이 를 그대로 따라 하는 말놀이, 수건을 이용하여 물건을 숨겨서 찾게 하는 놀이, 손쉬운 까꿍 놀이, 거울을 보며 아기 이름을
불러주거나 엄마 얼굴을 함께 보며 “엄마”라는 호칭을 알려주 는 거울 놀이, 표정과 발성을 흥내 내는 흥내 내기 놀이, 엄마 다리에서 비행기를 타는 비행기 놀이, 부모가 양쪽 이불을 잡 고 아기를 태운 후 천천히 그네처럼 흔들어 주는 이불그네 타기 놀이, 부드러운 스킨십으로 진정효과와 엄마와의 유대감을 높 일 수 있는 마사지놀이 등이 대표적인 영유아기의 애착놀이이 다. 애착놀이는 아기와 엄마와의 상호작용을 촉진하여 안정애 착을 형성하기에 적절할 뿐 아니라, 이를 통해 아기가 엄마에게 더 순응하는 태도를 보이며 특히 아기의 여러 가지 발달 중 의 사소통능력이 더욱 발달될 수 있다(Lee \& Kim, 2000). 특히 영유아는 몸의 감각으로 사물을 탐색하는 시기이므로 감각을 이용한 탐색 활동, 미술 활동, 언어 활동 등을 포함한 놀이를 통해 아기의 신체적, 자조적, 사회적, 지적, 언어적 발달을 도울 수 있다.

\section{CONCLUSIONS}

영유아기에는 시냅스와 뇌세포 연결망이 가장 왕성하게 발 달할 뿐 아니라 청각신경계를 포함한 전체 뇌 가소성도 매우 활발하게 발달하여 청각인지 및 뇌 발달을 촉진시키게 된다 (Harrison et al., 2005). 더욱이 청각신경계의 발달은 의사소통 및 언어인지 발달과 연계되어 있어 이 시기 청각신경계의 발달 은 매우 중요하다. 어린 동물을 대상으로 한 청각신경계의 실험 연구에서 와우를 제거를 하였을 때 나타나는 청력 손실 및 중 뇌의 청각 신경분포와 경로의 변화는 말초신경계가 중추신경 계에 미치는 영향을 증명하였다(Hashisaki \& Rubel, 1989). 더 욱이 조기 재활의 중요성은 친칠라의 실험에서 주파수 특이성 의 발달이 태생 후 1 2주 안에 완성되고 그 이후의 자극은 발 달에 소용이 없는 것으로 확인되었다(Harrison et al., 2005). 따 라서 말초신경계의 조기 자극이 청각신경계의 발달을 완성한다 고 결론 지을 수 있다. 이러한 결론은 영유아기의 자극이 아기 의 청각언어인지 발달에 얼마나 중대한 영향력이 있는지 설명 하고 있다. 특히 청각신경계의 말초신경능력이 부족하거나 거의 박탈된 상태로 태어나는 선천성 청각장애일 경우 영유아기에 듣 기를 보장구로 보완하고 부모와의 강력하고 밀착된 결속력으로 긍정적 상호작용과 스킨십이 강화된 애착육아는 장애의 영향을 최소화하고 인지능력을 정상범위에 가깝게 발달시킬 수 있는 단 초를 제공할 수 있다(Sharma et al., 2007). 따라서 영유아기에 여러 영역의 인지발달을 촉진시키는 애착육아는 특히 청각언 어인지능력 발달을 촉진할 수 있는 좋은 재활방법으로 적용될 수 있다. 한림대학교 언어청각학부 일반대학원의 영유아 청각 재활 연구팀에서 개발하고 있는 영유아의 조기 청능 재활 (KARI) 프로그램은 특히 애착육아의 다양한 방법을 접목하여 
개발되었다(Kim \& Yoon, 2016). KARI는 외국의 유명한 청각 언어인지 프로그램인 『Sensory Kids Impaired Home Inter-

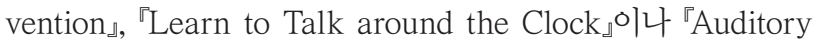
Verbal Therapy뿐 아니라 우리나라의 언어와 고유한 문화 및 육아 방식을 반영하여 1 24개월 영유아 시기에 적용할 수 있 는 청각장애 영유아를 위한 청각언어인지 재활 프로그램인데 구체적으로 회기 전 평가 자료, 부모 교육 및 상담 자료, 전문가 용 자료로 구성되어 있어 전문가나 부모가 손쉽게 따라 할 수 있도록 구성되어 있다. 애착육아법을 쉽게 실행하여 영유아 재 활에 도움이 될 수 있도록 여러 가지 방법과 예를 제시하고 있 는데 이 중 '우리 아이의 청각/언어 발달 촉진방법'은 애착육아 중 아기의 의도를 읽고 따라 하기, 아기의 반응에 민첩하게 반응 하기, 놀이를 이용하여 즐겁고 긍정적으로 자극하기 등의 방법 으로 애착육아의 상호작용을 적극적으로 반영하였다(Appen$\operatorname{dix}$ 2). 영유아의 특성에 맞게 쉽게 받아들일 수 있는 자극방법 과 즐거움을 강조하여 영유아 재활에 적절하게 개발된 '짧고 재 미있게 받아들이는 모델링 기법(short fun input for modeling)' 은 아기가 발성과 말을 효율적으로 모방할 수 있도록 하였는데, 눈 맞춤과 긍정적인 반응으로 아기와의 상호작용을 강조하여 애착 형성이 잘 이루어지도록 하였으며 뇌의 거울신경체계의 모방능력(Dinstein et al., 2008)이 극대화될 수 있도록 구성되 어 있어 모방을 통한 청각언어인지 재활의 실질적 효율성이 향 상되도록 하였다(Appendix 3). 또한 애착육아의 장점에서 제시 한 자존감과 독립심을 향상시킬 수 있는 '자기주도형 아기로 키 워요'는 아기가 스스로 결정할 수 있는 능력을 키우도록 기다려 주기, 한 박자 늦게 반응하기, 답은 아기가 하도록 하기 등이 강 조된 부모 교육 자료 중 하나로 구체적인 방법이 제시되어 부모 가 쉽게 따라 할 수 있도록 하였다. 또한 부모가 이런 애착육아 행동을 잘하고 있는지 스스로 점검할 수 있는 10 가지 점검 문 항도 함께 제시되어 자기주도형 청각언어 촉진 활동을 향상시 키고자 하였다. 상황별로 일상에서 청각언어인지 재활을 적용 하여 상호작용을 극대화할 수 있는 '우리 아이 매일매일 어떻게 말할까요라는 자료는 16 가지 상황 '아침에 일어날 때', '기저귀 갈 때', '목욕 전후, '마사지 할 때', '젖 먹일 때', '옷을 입고 벗을 때', '아이에게 밥 먹일 때', '책 읽기', '공 가지고 놀기', '아이 인형 이나 곰 인형 가지고 놀기', '퍼즐 가지고 놀기', '소꿉놀이하기', '놀이터에서 놀기', '색깔 찰흙 놀이', '빨래하기', '산책하기'별로 부모가 쉽게 따라 할 수 있도록 구체적인 청각언어인지 재활의 방법에 대한 예를 제시하여 그 상황에 맞춘 상호작용이 강화되 고 모방능력이 향상되도록 하였다(Granju \& Kennedy, 1999; Lee \& Kim, 2000; Sears \& Sears, 2011). 그 외, 스킨십을 강조 한 마사지 놀이와 부모가 적용할 수 있는 자료로 상호작용과 스킨십을 강조한 신체운동과 쉬운 언어 활동을 반복적으로 연
계할 수 있는 전통놀이인 단동십훈을 개월별로 적용할 수 있도 록 제시하였다. 이러한 다양한 애착육아 기법을 KARI에 반영 하고 접목한 청각언어인지 재활로 중추 청각신경계의 발달과 뇌 가소성을 활성화시켜 우리나라 청각장애 영유아의 조기 재활 효 능을 높이고자 하였다. 결론적으로 우리나라 선천성 청각장애 영유아도 청각장애지수가 매우 적은 아동으로 성장할 수 있도 록 최적의 청각언어인지 재활 시기를 놓치지 말고 애착육아 방 법을 적용하여 효율적인 중재를 제시하고 궁극적인 청각장애 아동의 복지를 구현하게 되기를 바란다. 또한 정상 영유아에게 적용되어 저출산시대에 귀한 우리나라의 아기들이 모두 부모와 행복한 영유아 시기를 통해 정서적으로 안정되고, 지혜롭고, 자 기주도적이고, 감성이 풍부한 사람으로 자라 주기를 바라는 마 음도 덧붙여 본고를 작성하였다.

중심 단어 : 애착육아·정서적 교류·전통육아·영유아의 조기 청능재활.

\section{Acknowledgments}

본 연구는 2015년 대한민국 교육부와 한국연구재단의 중견연구자 지원사업(인문사회: H00159) 지원을 받아 수행된 연구임(NRF-2015 S1A5A2A01011541).

\section{REFERENCES}

Ainsworth, M. D. S., Blehar, M. C., Waters, E., \& Wall, S. N. (1978). Patterns of Attachment: A Psychological Study of the Strange Situation. Hillsdale, NJ: Lawrence Erlbaum Associates.

Anisfeld, E., Casper, V., Nozyce, M., \& Cunningham, N. (1990). Does infant carrying promote attachment? An experimental study of the effects of increased physical contact on the development of attachment. Child Development, 61(5), 1617-1627.

Bhavnagri, N. (1984). Mother-Infant Interactions in Various Cultural Settings. Urbana, IL: ERIC Clearinghouse on Elementary and Early Childhood Education.

Becker, P. T., Grunwald, P. C., Moorman, J., \& Stuhr, S. (1991). Outcomes of developmentally supportive nursing care for very low birth weight infants. Nursing Research, 40(3), 150-155.

Bowlby, J. (1951). Maternal care and mental health. Bulletin of the World Health Organization, 3(3), 355-533.

Choi, Y. R. (2013). Traditional childcare that awakens the attachment instinct of mother's brain. Brain, 40, 36-39.

Chung, D. R. (2003). A review of traditional child-rearing practices in crosscultural perspective. Journal of Human Ecology, 8, 131-143.

Clopton, B. M. \& Silverman, M. S. (1977). Plasticity of binaural interaction. II. Critical period and changes in midline response. Journal of Neurophysiology, 40(6), 1275-1280.

Dinstein, I., Thomas, C., Behrmann, M. \& Heeger, D. J. (2008). A mirror up to nature. Current Biology, 18(1), R13-R18.

Glick, D. (1999 May 21). Breast-feeding is good for health and bonding. And mother's milk may have another payoff: Boosting a child's IQ scores. Newsweek. Seoul: Korea Joongang Daily.

Goodwin, D. (Executive Producer). (2007). Bring up Baby [Television broadcast]. London: Public Broadcasting Service.

Gottman, J. (2007). Raising an emotionally intelligent child: The heart of parenting. In Nam, E. Y. (Ed. and Trns.). Seoul: Korea Economic Daily \& Business Publications.

Granju, K. A. \& Kennedy, B. (1999). Attachment Parenting: Instinctive Care 
for Your Baby and Young Child. New York, NY: Pocket book.

Harrison, R. V., Gordon, K. A., \& Mount, R. J. (2005). Is there a critical period for cochlear implantation in congenitally deaf children? Analyses of hearing and speech perception performance after implantation. Developmental Psychobiology, 46(3), 252-261.

Hashisaki, G. T. \& Rubel, E. W. (1989). Effects of unilateral cochlea removal on anteroventral cochlear nucleus neurons in developing gerbils. Journal of Comparative Neurology, 283(4), 5-73.

Hong, G. J. \& Lee, E. J. (2017). The effects of parents' autonomy supports and controls on adolescents' academic achievements and peer attachments: Longitudinal mediating effects of self-determined motivations. The Korean Journal of Educational Psychology, 31(2), 305-326.

Huh, I. W. (2010). A Lifetime of Nobleman in Old Painting. (1st ed.). Paju: Dolbegae.

Hunziker, U. A. \& Barr, R. G. (1986). Increased carrying reduces infant crying: A randomized controlled trial. Pediatrics, 77(5), 641-648.

Jin, M. K. \& Yoo, M. S. (2005). The distributions of attachment classifications and attachment behaviors of Korean infants and American infants. Korean Journal of Child Studies, 26(6), 17-28.

Kennedy, A., Kennell, J. H., Klaus, M., Klaus, P., \& Simkin, P. (1992). DONA (Doulas Of North America) international history. DONA International. Retrieved from https://www.dona.org/the-dona-advantage/about/history/.

Kim, E. H., Choi, H. H., Lee, S. H., \& Bang, H. J. (2005). Attachment behavior characteristics of infants in the strange situation procedure. Korean Journal of Child Studies, 26(4), 35-53.

Kim, J. S. (2017). Pediatric audiology. In Choi, C. H., Lee, J. Y., Han, W. J., Lee, J. H., Kim, J. S., Cho, S. J., et al. (2nd ed.). Introduction to Audiology. (pp. 299-330). Seoul: Hakjisa.

Kim, J. S. \& Yoon, J. E. (2016). Development of Korean aural rehabilitation for infants. Audiology and Speech Research, 12(Suppl 1), S41-S46.

Kim, K. H. (Producer). (2012, May 03). Old Future of Traditional Parenting Secrets [Television broadcast]. Education Broadcasting System (EBS). Retrieved from http://www.ebs.co.kr/tv/show?prodId=348\&lectId= 3107516.

Kwak, K., Kim, S., \& Jeong, Y. (2005). Infants' sensitivity on the changes of mothers' touch. Korean Journal of Child Studies, 26(5), 123-137.

Lee, Y. \& Kim, O. G. (2000). The effects of $\ulcorner$ mom and baby program $\lrcorner$ on the mother-toddler relationships and toddler's development. Korean Journal of Early Childhood Education, 20(3), 67-84.

Levi-montalcini, R. (1949). The development of the acoustico-vestibular centres in the chick embryo in the absence of the afferent root fibers and of descending fiber tracts. The Journal of Comparative Neurology, 91(2), 209-241.

Lim, S. Y. \& Kim, E. J. (2010). Infant educational implications of Korean traditional infants play. The Journal of Child Education, 19(2), 175-191.
McKinney, C., Milone, M. C., \& Renk, K. (2011). Parenting and late adolescent emotional adjustment: Mediating effects of discipline and gender. Child Psychiatry Hum Development 42(4), 463-481.

National Institutes of Health (NIH). (1994). What Is a Safe Sleep Environment? Safe to Sleep. Retrieved from https://www.nichd.nih.gov/sts/ about/environment/Pages/default.aspx.

Nicholson, B. \& Parker, L. (1994). Attachment Parenting International (API). Retrieved from http://www.attachmentparenting.org/.

Pickert, K. (2012 May 21). The Man Who Remade Motherhood. Times. New York, NY: Time Warner.

Schore, A. N. (1996). The experience-dependent maturation of a regulatory system in the orbital prefrontal cortex and the origin of developmental psychopathology. Development and Psychopathology, 8(1), 59-87.

Sears, W. (1983). Creative Parenting: How to Use the Attachment Parenting Concept to Raise Children Successfully from Birth through Adolescence. New York, NY: Dodd, Mead \& Co.

Sears, W. \& Sears, M. (2011). The Attachment Parenting Book: A Common Sense Guide to Understanding and Nurturing Your Baby. In Kim, S. Y. (Ed. and Trns.). Goyang: Purnyuga.

Sharma, A., Gilley, P. M., Dorman, M. F., \& Baldwin, R. (2007). Deprivationinduced cortical reorganization in children with cochlear implants. International Journal of Audiology, 46(9), 494-499.

Solter, J. A. (2015). Attachment Play (How to Solve Children's Behavior Problems with Play, Laughter, and Connection). In Kim, M. N. (Ed. and Trns.). Seoul: Hakjisa.

Stapleton, L. R., Schetter, C. D., Westling, E., Rini, C., Glynn, L. M., Hobel, C. J., et al. (2012). Perceived partner support in pregnancy predicts lower maternal and infant distress. Journal of Family Psychology, 26(3), 453-463.

Tettinntil. (2008, Apr. 21). Narrow Podaegi on the back (How to use Podaegi) [Video file]. Retrieved from https://www.youtube.com/watch?v=NZbKnK_IhqE.

Tobey, E. A., Thal, D., Niparko, J. K., Eisenberg, L. S., Quittner, A. L., Wang, N. Y.; CDaCI Investigative Team. (2013). Influence of implantation age on school-age language performance in pediatric cochlear implant users. International Journal of Audiology, 52(4), 219-229.

Wiesel, T. N. \& Hubel, D. H. (1965). Comparison of the effects of unilateral and bilateral eye closure on cortical unit responses in kittens. Journal of Neurophysiology, 28(6), 1029-1040.

You, H. S. (2003). Relationship between the security of children's attachment and their emotional intelligence. The Korean Journal of Human Development, 10(2), 19-31.

Yu, H., J., Kang, Y., \& Lee, H. I. (2004). The effects of maternal attachment styles and types of children's disorders on rearing attitude and parenting stress. Korean Journal of Clinical Psychology, 23(1), 77-89. 


\section{APPENDICES}

\section{Appendix 1. 단동십훈(檀童十訓)}

단동십훈이란 오천 년 선조의 지혜가 깃든 우리나라 전통놀이로 단군시대부터 구전되어 내려온 우리 민족의 전통육아법입니다. 아이와 엄마의 상호작용을 강조하는 교훈이 담긴 10 가지 동작놀이입니다. 10 가지 동작놀이는 불아불아, 시상시상, 도리도리, 지암 지암, 곤지곤지, 섬마섬마, 업비업비, 아함아함, 짝짝궁짝짝궁, 질라아비 휠휠의로 구성되어 있습니다. 각 훈의 의미에 따른 동작은 발달에 따라 적절한 월령에 적용하여 청능 재활 및 언어 발달에 응용할 수 있습니다.

\begin{tabular}{|c|c|c|c|c|}
\hline 번호 & 단동십훈 & 미 & 동 & 시행 월령 \\
\hline 1 & $\begin{array}{l}\text { 불아불아 } \\
\text { (弗亞弗亞) }\end{array}$ & $\begin{array}{l}\text { 하늘로부터 온 아기의 생명을 존중 } \\
\text { 하는 의미 }\end{array}$ & $\begin{array}{l}\text { 아기의 겨드랑이나 허리를 잡고 좌우로 흔들며 } \\
\text { 움직인다. 척추신경, 하체 강화 }\end{array}$ & 6개월 이상 \\
\hline 2 & $\begin{array}{l}\text { 시상시상 } \\
\text { (詩想詩想) }\end{array}$ & $\begin{array}{l}\text { 아기 몸에 우주가 있으니 우주의 } \\
\text { 섭리에 순응하는 의미 }\end{array}$ & $\begin{array}{l}\text { 아이를 앉혀 놓고 두 팔이나 허리를 잡고 앞뒤로 } \\
\text { 흔든다. 몸의 중심 잡기 }\end{array}$ & 6개월 이상 \\
\hline 3 & $\begin{array}{l}\text { 도리도리 } \\
\text { (道理道理) }\end{array}$ & $\begin{array}{l}\text { 천지만물이 하늘의 도리로 } \\
\text { 생겼으니 이에 맞게 살라는 의미 }\end{array}$ & $\begin{array}{l}\text { 아이의 머리를 좌우로 흔든다. } \\
\text { 척수와 뇌수의 균형적 발전 활성화 }\end{array}$ & 4 5개월 \\
\hline 4 & $\begin{array}{l}\text { 지암지암 } \\
\text { (持闇持闇) }\end{array}$ & $\begin{array}{l}\text { 혼미한 것을 두루두루 헤아려 파악 } \\
\text { 하라는 의미 }\end{array}$ & $\begin{array}{l}\text { 두 손을 폈다 쥐었다 하는 동작 } \\
\text { 미세근육을 통해 심장의 혈액순환과 뇌의 기능 강화 }\end{array}$ & 3 4개월 \\
\hline 5 & $\begin{array}{l}\text { 곤지곤지 } \\
\text { (坤地坤地) }\end{array}$ & $\begin{array}{l}\text { 음양의 조화를 이루며 덕을 } \\
\text { 쌓으라는 의미 }\end{array}$ & $\begin{array}{l}\text { 한 손을 편 후, 반대 손 검지로 손바닥을 찍는 동작 } \\
\text { 손과 눈의 협응력 향상, 심장과 뇌의 활동 강화 }\end{array}$ & 8 9개월 \\
\hline 6 & $\begin{array}{l}\text { 섬마섬마 } \\
\text { (西摩西摩) }\end{array}$ & $\begin{array}{l}\text { 바른길에 서며 독립적으로 살라는 } \\
\text { 의미 }\end{array}$ & $\begin{array}{l}\text { 엄마의 손바닥 위에 아이를 세워 올리는 동작 } \\
\text { 다리의 힘을 길러주며, 균형감각 향상 }\end{array}$ & 9 11개월 \\
\hline 7 & $\begin{array}{l}\text { 업비업비 } \\
\text { (業非業非) }\end{array}$ & $\begin{array}{l}\text { 이치에 맞지 않는 행동은 삼가라는 } \\
\text { 의미 }\end{array}$ & $\begin{array}{l}\text { 양 팔을 아래로 뻗어 손바닥을 흔드는 동작 } \\
\text { 도에 맞지 않는 일이나 무서움을 가르칠 수 있음 }\end{array}$ & 4 5개월 \\
\hline 8 & $\begin{array}{l}\text { 아함아함 } \\
\text { (\zh21⼀ㅁ욭⿱⼈) }\end{array}$ & $\begin{array}{l}\text { 포자를 소리 내어 아기가 작은 } \\
\text { 우주임을 알리는 의미 }\end{array}$ & 손바닥으로 입을 막으며 소리를 내는 동작 & 9 11개월 \\
\hline 9 & $\begin{array}{l}\text { 짝짝궁짝짝궁 } \\
\text { (作作弓作作弓) }\end{array}$ & $\begin{array}{l}\text { 천지의 조화를 꾀하고 하늘의 } \\
\text { 이치를 알리는 의미 }\end{array}$ & $\begin{array}{l}\text { 두 손바닥을 마주쳐 소리를 내는 동작 } \\
\text { 뇌 기능 활성화 }\end{array}$ & 6 8개월 \\
\hline 10 & $\begin{array}{l}\text { 질라아비 휠휠의 } \\
\text { (羅呵備 活活議) }\end{array}$ & $\begin{array}{l}\text { 어떤 질병도 없이 훨훨 날아 } \\
\text { 활기차게 자라라는 의미 }\end{array}$ & $\begin{array}{l}\text { 앉은 채로 두 팔을 날개처럼 벌리고 흔드는 동작 } \\
\text { 손과 눈의 협응력을 길러주며, 혈액순환 촉진 }\end{array}$ & 6개월 이상 \\
\hline
\end{tabular}




\section{Appendix 2. 우리 아이의 청각/언어 발달 촉진 방법}

\section{- 아기에게 말할 때}

- 아기와 눈 맞춤을 하고 모든 행동과 발성에 미소와 함께 긍정적 코멘트를 하세요.

- 단순하고 짧은 행동과 말로 아기에게 이야기해 주세요.

- 아이가 집중하는 동안 목표행동과 말을 반복적으로 하세요. 반복적인 행동과 말에 먼저 지루해지는 사람은 어른입니다. 재미있는 행동과 말을 반복하면 아기들은 오래 집중할 수 있습니다.

- 장난감으로 놀 때, 장난감의 위치는 얼굴 주변으로 하여 부모가 말하는 동안 집중할 수 있도록 도와주세요.

- 사물을 제시하기 전에 사물의 이름을 먼저 말하여 듣기를 연습할 기회를 제공하세요. 예를 들어, '우유 먹을까?'라고 먼저 말하여 아기가 우유를 보기 전에 ‘우유’라는 단어를 듣고 생각할 기회를 준 후 우유를 주세요.

\section{- 아기가 말하도록 할 때}

- 아기의 발성과 행동을 관찰하고 아기가 발성하면 즉각적으로 따라 하세요.

- 차례차례하기(turn-taking)놀이를 해보세요. 예를 들어, 아기가 /아 아/ 하면 동일한 억양으로 부모가 /아 아/ 하고 대답합니다. 그리고 아기가 말할 차례임을 아기의 눈을 보고 기다리는 행동으로 알려줍니다.

- 새로운 자발적 발성이나 조음이 나타나면 따라 하고 그 발성이나 조음에 관련된 놀이로 더 자극하세요.

- 발성이나 조음이 맞건 틀리건 발성을 이용하여 의사를 표현하면 칭찬해 주세요. 이러한 과정이 말이나 발성 이용의 중요성을 알 게합니다.

\section{- 소리와 언어가 풍부한 환경을 조성하고자 할 때}

• 아기가 집중하는 소리(예를 들어 차, 문, 노크, 초인종, 전화기 소리 등)와 관련된 놀이와 말로 연결해 보세요.

- 청각언어인지 재활 시간이 재미없으면 더 이상 아기는 집중하지 않습니다. 특정 행동이나 발성을 너무 강요하지 말고 재미있는 시 간을 만들어 보세요. 부모와 아기 모두 재활 시간이 즐거워야 합니다.

- 책은 매일매일 읽어 주세요. 


\section{Appendix 3. 짧고 재미있게 받아들이는 모델링 기법(Short Fun Input for Modeling, SFIM)}

() SFIM은 집중 시간이 짧은 영유아가 자극을 쉽게 받아들일 수 있도록 짧고 재미있게 자극을 제시하여 따라 하기의 효율성을 높 인 독특한 구조의 모델링 기법입니다.

(ن) 5 초 단위의 모델링과 기다리기: 1 초 모델링 자극 $+i \overline{4}$ 초 기다리기 !

아이의 눈을 쳐다보면서 모방을 기다리는 행동을 통해 아이가 따라 하도록 유도하는 시간

(ن) 5초 단위의 모델링을 1분간 12번 반복해서 제시하세요.

(-) 1분의 모델링은 하루 5 회 이상 제시하세요.

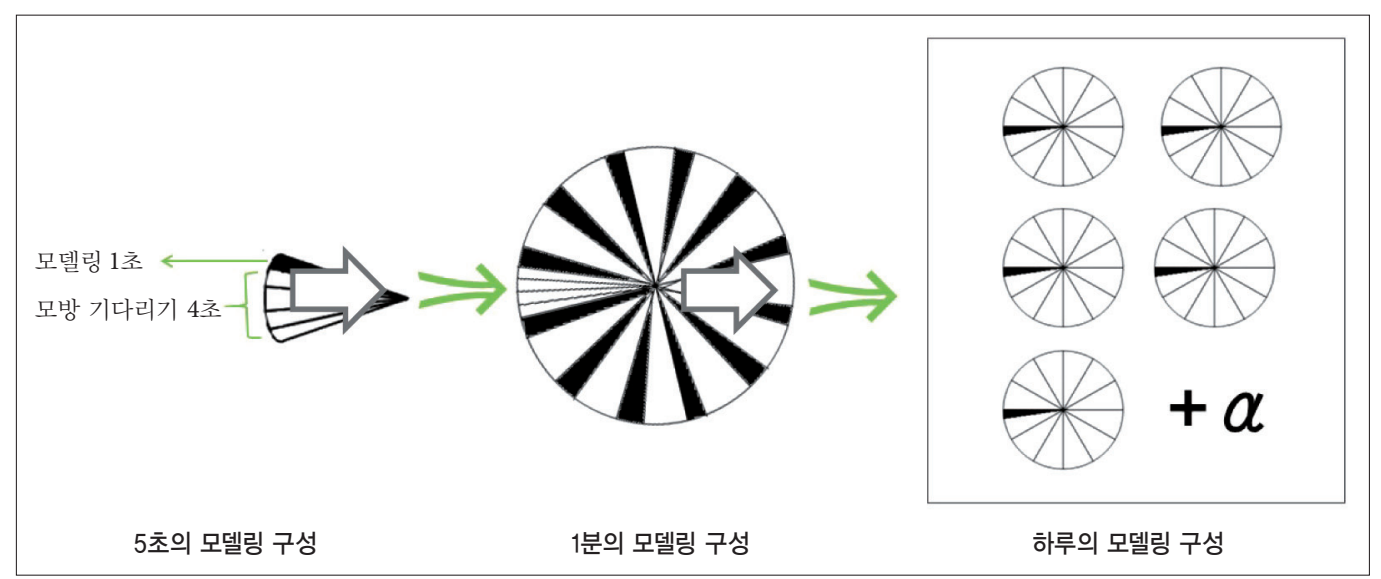

SFIM은 언제 실시하나요?

아이가 기분 좋은 시간에 실시하세요.

SFIM은 어떻게 실시하나요?

재미있는 표정과 몸짓으로 발성이나 말 자극을 1초간 제시하고 4초간 눈을 보며 기다려 주세요.

SFIM은 얼마 동안 실시해야 하나요?

1 분간(12개의 5 초 단위 모델링)의 모델링 자극을 하루 적어도 5 회 이상 실시하세요.

SFIM은 무엇을 실시하나요?

시기에 맞는 발성과 말 자극을 제시하세요. 예를 들어 우유를 들고 “우”라는 자극을 1초간 제시하세요. 